九州大学学術情報リポジトリ

Kyushu University Institutional Repository

\title{
Genetic Diversity in Vietnamese Upland Rice Germplasm Revealed by SSR Markers
}

Nguyen, Thuy T. T.

Department of Molecular Biology, Agricultural Genetics Institute

Nguyen, Nguyet M. T.

Department of Molecular Biology, Agricultural Genetics Institute

Hoang, Long $\mathrm{H}$.

Department of Molecular Biology, Agricultural Genetics Institute

Furuya, Naruto

Faculty of Agriculture, Kyushu University

他

https://doi.org/10.5109/25195

出版情報：九州大学大学院農学研究院紀要. 57 (2)，pp. 383-391，2012-09-20. Faculty of Agriculture, Kyushu University

バージョン :

権利関係 : 


\title{
Genetic Diversity in Vietnamese Upland Rice Germplasm Revealed by SSR Markers
}

\author{
Thuy T. T. NGUYEN ${ }^{1 *}$, Nguyet M. T. NGUYEN ${ }^{1}$, Long H. HOANG ${ }^{1}$, \\ Naruto FURUYA ${ }^{2}$ and Kenichi TSUCHIYA ${ }^{2}$
}

\author{
Laboratory of Plant Pathology, Division of Agricultural Bioresource Science, \\ Department of Bioresource Science, Faculty of Agriculture, \\ Kyushu University, Fukuoka 812-8581, Japan \\ (Received April 5, 2012 and accepted May 10, 2012)
}

\begin{abstract}
Tolerance to water deficit condition is an important prerequisite for optimal performance of rice in drought prone environments. The purpose of this study was to evaluate the genetic diversity within upland rice accessions, collected from Northern part of Vietnam. Genetic diversity of the rice varieties was evaluated at the DNA level. Forty-one accessions were surveyed with 30 simple sequence repeat (SSR) markers revealing the genetic relationship among the varieties. A total of 192 polymorphic bands were detected. The number of alleles per locus ranged from 3 to 12 , with an average of 6.4. Cluster analysis based on genetic similarities grouped the rice accessions into two major groups. These groups were divided into five subgroups. These clusters agree with origin information available on the accessions. The results suggested that a relatively small number of SSR markers could be used for analysis of genetic diversity in rice germplasm. The upland rice germplasm presents a valuable gene source and sufficient genetic background for future breeding and mapping works on drought tolerance rice in Vietnam.
\end{abstract}

Keywords: allele, drought tolerance, genetic diversity, rice

\section{INTRODUCTION}

Drought is an important factor which affected the world food security can cause $70 \%$ of yield loss (Bray et al., 2000). Forty six thousand ha of rice land in Asia cultivated under rainfed condition every year. In Vietnam, the rice planting area is approx. 6 million ha. Of which, 1.5 million ha are rainfed and highland area. Twenty percent of the poor ethnic minority people that account for $20 \%$ of total population, live on rice production and have important responsiblity for the forest and watershed protection. Making them selfsufficient in food shall be defined as very important task in the development strategy of the country. It is suggested that with losses of arable land in delta areas due to the raised water level, rice production in these areas should be shifted to highland regions. In addition, insufficient water for rice production frequently happens even though in lowland irrigated rice fields bring measurable yield damage, affected rice farmer life. The development of drought tolerant cultivars is an effective approach for the contribution to the secure of stable rice production, increase rice farmer income and reduce poverty in Asia. However, attempts of the development of the cultivars with improved yield production were not much succeeded.

Rice has one of the largest ex situ germplasm collection in the world (Jackson and Juggan, 1993). This germplasm has made great contributions to rice breeding (Junjia, et al., 2002). Much success has been made in

\footnotetext{
1 Department of Molecular Biology, Agricultural Genetics Institute, Pham Van Dong, Hanoi, Vietnam

2 Faculty of Agriculture, Kyushu University, Hakozaki, Fukuoka 812, Japan

* Corresponding author (E-mail: thuynt.khcn@mard.gov.vn)
}

rice breeding in Vietnam with an average yield of 3.69 tones per ha in 1995 to 5.23 tones per ha in 2009 (General Statistics Office of Vietnam, 2010, http://www.gso.gov. vn). However, this value is equivalent to rice yield in China of 3.35 tones per ha in the 1950s and 6.23 tones per ha in the 1990s (Yongwen et al., 2006). Since 1996, rice cultivars from different Vietnam ecosystems throughout the country have been collected by National Plant Resource Center and maintained ex situ, including over 3,000 accessions in the National Genebank. However, the evaluation of germplasm has been performed only for morphological traits. The molecular tools have not been used systematically to evaluate large Vietnamese rice germplasm. Despite the richness of genetic resources, only a small proportion of this rice germplasm collection has been used in national rice breeding program. A few preliminary studies indicated that the gene sources for drought tolerance are quite abundant in Vietnamese local rice cultivars (Lang et al., 2009). However, the exploitation and efficient application of the gene sources are still limited.

Molecular markers have been used extensively to determine the genetic structure and diversity pattern of rice cultivar of interest (Herrera et al., 2008). Compared to morphological analysis, molecular markers can reveal differences among accessions at DNA level and thus provide a more direct reliable and efficient tool for germplasm conservation and management. The knowledge regarding the amount of genetic variation in germplasm accession and genetic relationships among genotypes is an important consideration for designing effective breeding programs (Herrera et al., 2008). Different types of molecular markers are available for evaluation of genetic variation in rice: restriction fragment length polymorphism (RFLP) (Botstein et al., 1980), random amplified 
polymorphism DNA (RAPD) (William et al., 1990), amplified fragment length polymorphism (AFLP) (Vos et al., 1995), and simple sequence repeat (SSR) (Tautz, 1989). The AFLP marker has proven to be useful for characterization of the closely related rice cultivars (Spada et al., 2004). SSR approach is more suitable for differentiation of the closely related genomes, to study family structure, and to allow allelic changes due to their ability to detect higher polymorphism and codominance (Akagi et al., 1997).

Numerous studies on rice genetic diversity have been performed using molecular markers to analyze wild population or landraces in different countries (Jayamani et al., 2007). More concern is often expressed at cultivars because the domestication and modern plant breeding have led to a reduction in the genetic diversity of crops and loss of genes, which could result in dramatic consequences in crop production, such as genetic vulnerability to novel pests, diseases and climatic changes (Roussel et al., 2004). Genetic diversity of Vietnamese local rice landraces have been performed with 200 salt tolerance assessions. However, the study was assessed using agro-morphological characters (Lang et al., 2009). The same research was conducted with traditional upland rice varieties in the Philippines using morphometric markers (Florence et al., 2010).

In this context, to ensure food security and stable development of agriculture rice land areas will be

Table 1. Distribution of the upland and improved Vietnamese rice germplasm used in present study

\begin{tabular}{|c|c|c|c|}
\hline Code & Name & Location & Cultivation \\
\hline \multicolumn{4}{|c|}{ Upland varieties } \\
\hline 842 & Nhong Haiduong & Red river delta & Summer season \\
\hline 1832 & Khau nuot cung & Northeastern & Summer season, terraced field, rained field \\
\hline 1837 & Lua mo trang & Northeastern & Summer season, terraced field, rained field \\
\hline 2125 & Ble' tolo & Northwest & Summer season, upland variety \\
\hline 2127 & Ble blu & Northwest & Summer season, upland variety \\
\hline 2131 & Ble la tong & Northwest & Summer season, upland variety \\
\hline 2135 & Ble lenh xi & Northwest & Summer season, upland variety \\
\hline 2367 & Nep cuc & Red river delta & Spring season, field in hollows land, rained field \\
\hline 2642 & B'le la & Northeastern & Summer season, irrigated field, cultivated rice \\
\hline 3550 & Chanh trui & North Central & Spring season, field in hollows land, cultivated rice \\
\hline 3935 & Mong lu & Northwest & Summer season, upland variety \\
\hline 3970 & Ble ch-cau & Northwest & Summer season, upland variety \\
\hline 4123 & Khau lay khao & Northeastern & Summer season, upland variety \\
\hline 4723 & Cham soong & North Central & Summer season, upland variety \\
\hline 4726 & Nep cai can & North Central & Summer season, upland variety \\
\hline 4748 & Hang ngua & North Central & Summer season, upland variety \\
\hline 4762 & Lo cang & North Central & Summer season, upland variety \\
\hline 4792 & Khau ma giang & North Central & Summer season, upland variety \\
\hline 4793 & Khau non & North Central & Summer season, upland variety \\
\hline 4794 & Khau hin & North Central & Summer season, upland variety \\
\hline 4806 & Blao sinh sai & Northwest & Summer season, upland variety \\
\hline 4840 & Blao dong & Northwest & Summer season, upland variety \\
\hline 4843 & Blao co nem & Northwest & Summer season, upland variety \\
\hline 5011 & Khau noong mo & North Central & Summer season, upland variety \\
\hline 5015 & Chao luu & North Central & Summer season, upland variety \\
\hline 5018 & Khau san & North Central & Summer season, upland variety \\
\hline 5020 & Khau do don & North Central & Summer season, upland variety \\
\hline 5057 & Khau cu & North Central & Summer season, upland variety \\
\hline 6111 & Te tep & Red river delta & Lowland variety \\
\hline 6188 & Cuom dang 1 & Red river delta & Spring season, irrigated field, cultivated rice \\
\hline 6203 & Ngoi tia & Red river delta & Spring season, field in hollows land, cultivated rice \\
\hline 6430 & Khau ken & Northeastern & Summer season, upland variety \\
\hline 6432 & Bieo hong sui & Northeastern & Summer season, upland variety \\
\hline 7349 & Manh gie & North Central & Summer season, upland variety \\
\hline \multicolumn{4}{|c|}{ Commercial varieties } \\
\hline 4666 & IR64 & Introduced from IRRl & Lowland variety \\
\hline N/A & Jasmine 85 & Thailand origin & Lowland variety \\
\hline N/A & SL12 & Northern cultivated & Irrigated field, cultivated rice \\
\hline N/A & DT54 & Northern cultivated & Irrigated field, cultivated rice \\
\hline 8177 & Khang Dan & China origin & Irrigated field, cultivated rice \\
\hline 8179 & Q5 & China origin & Irrigated field, cultivated rice \\
\hline N/A & LT25 & Northern cultivated & Irrigated field, cultivated rice \\
\hline
\end{tabular}


expanded to the high land area, where the irrigation is depended on the rainfall. Therefore, the deployment of the basic research on drought tolerance in rice plays an important role in the application and development research. The objectives of this study were: (1) to evaluate the genetic diversity among selected local Vietnamese rice gene pool, paying particular attention to variation among potential drought tolerant varieties; and (2) to determine rice accessions with high genetic diversity that will be used to develop mapping population for construction of rice drought quantitative trait locus (QTL) maps and marker-assisted molecular breeding of high yield rice variety with drought tolerance.

\section{MATERIALS AND METHODS}

\section{Rice germplasm}

Rice germplasm (Table 1) were kindly provided by National Gene Bank of Plant Resource Center of Vietnam, represented the different unique upland cultivars of Northern part, which have been evaluated for drought tolerance and showed high level of resistance to water deficit condition (data not shown). A total of 41 accessions including 34 local drought tolerant varieties distributed in twelve provinces and 7 varieties originated from others in order to compare the genetic diversity of Vietnam unique upland rice germplasm and identify gene source for breeding program of drought tolerance in rice.

\section{SSR analysis}

Fresh leaf tissues were harvested at the seedling stage from plants grown in the greenhouse. Total genomic DNA was extracted from parental lines leaf tissues using $\mathrm{NaOH}$ extraction method improved from the simple method of preparing plant samples for PCR (Wang et al., 1993). Thirty SSR markers covering all the twelve chromosomes on rice genome were selected for the genetic diversity analysis based on the Gramene Markers Database (http://www.gramene.org/markers/). These markers were chosen based on ability to be high polymorphic among rice varieties in the preliminary screening performed in previous studies. PCR was performed in $15 \mu \mathrm{l}$ reaction mixture containing $30 \mathrm{ng}$ of template DNA, $0.4 \mu \mathrm{M}$ of each primer, $200 \mu \mathrm{M}$ for each dNTPs, $1 \mathrm{x}$ PCR buffer (10 mM Tris-HCl, $50 \mathrm{mM} \mathrm{KCl,} 1.5 \mathrm{mM} \mathrm{MgCl}_{2}$ ) and 1.0 units Taq DNA polymerase (Takara) in a 96 wells PCR plate. An Verity 96 Well Thermal Cycler (Applied Biosystems Co. Ltd.,) was used along with the following PCR profile: an initial denaturing step of $5 \mathrm{~min}$ at $94^{\circ} \mathrm{C}$, followed by 35 cycles of $30 \mathrm{sec}$ at $94^{\circ} \mathrm{C}, 30 \mathrm{sec}$ at $55^{\circ} \mathrm{C}$, $1 \mathrm{~min}$ at $72^{\circ} \mathrm{C}$, and a final extension at $72^{\circ} \mathrm{C}$ for $7 \mathrm{~min}$. Amplified products were resolved on $3 \%$ agarose gels with ethidium bromide staining. Gels were visualized under ultraviolet light using Herolab, Germany. The size in nucleotide base pairs (bp) of allele band with highest intensity for each SSR marker was scored as main allele band and determined based on its migration relative to 50 bp DNA ladder (Fermentas, Lithuania).

\section{Data analysis}

The allelic diversity of the SSR was calculated according to the Polymorphism Information Content, PIC, described by Anderson et al. (1993), in the following formula:

$$
\mathrm{PIC}_{i}=1-\sum_{j=1}^{n} \mathrm{P}_{i j}^{2}
$$

Where $\mathrm{p}_{i j}$ is the frequency of $j$ th allele at the locus $i$ and summation extends over $n$ alleles. Heterogeneity (HG) by accession and by marker was calculated as percentage of heterogeneous loci per accession across all accessions and loci, respectively. For the diversity representation, markers were scored based on the band pattern generated from the gel imaging system for the presence or absence of the corresponding band among the genotypes and then converted to a genetic similarity (GS) matrix using Dice coefficients (Sneath and Sokal, 1973). Using the binary coding system, ' 1 ' indicates the presence of clear and unambiguous bands and ' 0 ' indicates the absence of bands. A genetic relationship matrix was used to produce a dendrogram in a sequential agglomerative hierarchical nested cluster analysis (SAHN), based on the unweighted pair-group method with arithmetical average (UPGMA) clustering of the GS matrix.

\section{RESULTS}

\section{SSR diversity}

The 41 rice accessions were analyzed with 30 SSR markers and all of them were shown polymorphic with 192 bands. The size of PCR products ranging from $65 \mathrm{bp}$ to $280 \mathrm{bp}$ across 41 rice varieties for each of the 30 markers (Fig. 1 and Table 2).

There was no correlation detected between the number of alleles and the number of repeats in SSR loci (Table 2). The number of alleles per locus ranged from 3 alleles (RM3431) to 12 alleles (RM1364), with an average of 6.4 alleles across the 30 loci. The PIC values ranged from 0.447 (RM3431) to 0.888 (RM3515), with an average of 0.735 . Unique allele, an allele that was observed in only one of the 41 rice varieties, were identified at 16 loci in total of 30 loci, with the maximum of 3 unique alleles in RM1364 locus and RM3476 locus. The frequency of the most common allele at each locus ranged from $13.95 \%$ (RM3515) to $71.43 \%$ (RM3431). On average, $37.76 \%$ of the 41 rice accessions shared a common major allele at any given locus (Table 2).

The average HG percentage of the 30 SSR markers over all 41 accessions (Table 2) was accounted for 5.28\%. Fifteen of the 30 (50\%) SSR markers detected no heterogeneous accessions, while the remaining markers showed one or more heterogeneous accessions. Remarkably, RM5599 detected cultivar heterogeneity in 21 accessions ( $\mathrm{HG}=51.22)$, and RM1364 detected cultivar heterogeneity in 17 accessions $(\mathrm{HG}=41.46)$ while the remaining 13 SSR markers identified one to four heterogeneous accessions ( $\mathrm{HG}=2.44$ to $\mathrm{HG}=9.76)$. Determination of the $\mathrm{HG} \%$ of 41 accessions across all SSR markers (Table 3 ) revealed that 24 accessions were homogeneous at all loci and 17 


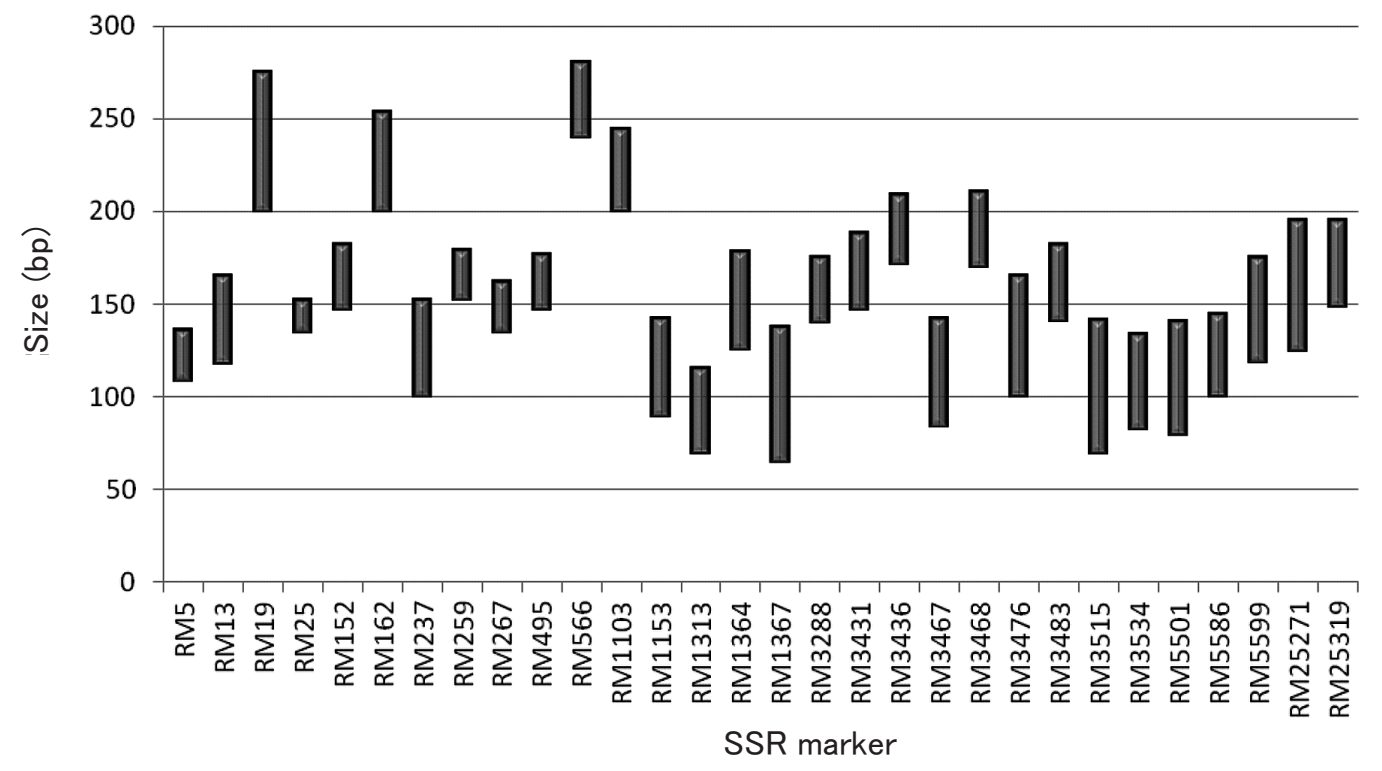

Fig. 1. Allele size variation of the surveyed SSR loci.

Table 2. Allele variation, Polymorphism Information Content (PIC) and heterogeneity (HG\%) for SSR loci identified in 41 rice varieties

\begin{tabular}{|c|c|c|c|c|c|c|c|}
\hline Marker & $\begin{array}{c}\text { Chromosome } \\
\text { location }\end{array}$ & $\begin{array}{l}\text { No. of } \\
\text { allele }\end{array}$ & $\begin{array}{l}\text { PCR product } \\
\text { size (bp) }\end{array}$ & $\begin{array}{l}\text { Frequency of the } \\
\text { most common allele }\end{array}$ & $\begin{array}{l}\text { Unique } \\
\text { allele }\end{array}$ & PIC & HG (\%) \\
\hline RM5 & 1 & 7 & 109-136 & 24.39 & 0 & 0.844 & 0 \\
\hline RM13 & 5 & 5 & $118-165$ & 41.463 & 0 & 0.709 & 0 \\
\hline RM19 & 12 & 5 & $200-275$ & 36.585 & 0 & 0.746 & 0 \\
\hline RM25 & 8 & 4 & $135-152$ & 51.22 & 1 & 0.563 & 0 \\
\hline RM152 & 8 & 5 & $147-182$ & 51.22 & 0 & 0.657 & 0 \\
\hline RM162 & 6 & 6 & $200-253$ & 26.829 & 0 & 0.813 & 0 \\
\hline RM237 & 1 & 4 & $100-152$ & 51.22 & 0 & 0.651 & 0 \\
\hline RM259 & 1 & 6 & $153-179$ & 20.93 & 0 & 0.829 & 4.88 \\
\hline RM267 & 5 & 6 & 135-162 & 51.163 & 2 & 0.654 & 7.32 \\
\hline RM495 & 1 & 6 & $147-176$ & 42.857 & 1 & 0.709 & 4.88 \\
\hline RM566 & 9 & 7 & $240-280$ & 26.19 & 1 & 0.808 & 2.44 \\
\hline RM1103 & 12 & 4 & 200-244 & 35.897 & 0 & 0.707 & 0 \\
\hline RM1153 & 4 & 7 & 90-142 & 39.535 & 2 & 0.677 & 4.88 \\
\hline RM1313 & 2 & 7 & $70-115$ & 26.829 & 2 & 0.795 & 0 \\
\hline RM1364 & 7 & 12 & $126-178$ & 24.561 & 3 & 0.855 & 41.46 \\
\hline RM1367 & 2 & 7 & $65-137$ & 39.024 & 1 & 0.74 & 0 \\
\hline RM3288 & 4 & 5 & $140-175$ & 26.19 & 0 & 0.787 & 2.44 \\
\hline RM3431 & 6 & 3 & $147-188$ & 71.429 & 0 & 0.447 & 0 \\
\hline RM3436 & 3 & 5 & $172-209$ & 48.718 & 1 & 0.68 & 0 \\
\hline RM3467 & 3 & 7 & 84-142 & 37.209 & 0 & 0.778 & 4.88 \\
\hline RM3468 & 1 & 9 & $170-210$ & 19.048 & 1 & 0.864 & 2.44 \\
\hline RM3476 & 5 & 7 & $102-165$ & 54.545 & 3 & 0.642 & 7.32 \\
\hline RM3483 & 12 & 3 & $141-182$ & 41.026 & 0 & 0.657 & 0 \\
\hline RM3515 & 2 & 10 & $70-141$ & 13.953 & 0 & 0.888 & 9.76 \\
\hline RM3534 & 4 & 7 & 83-133 & 41.463 & 1 & 0.751 & 0 \\
\hline RM5501 & 1 & 7 & $80-140$ & 51.163 & 0 & 0.698 & 7.32 \\
\hline RM5586 & 4 & 7 & $100-144$ & 32.432 & 2 & 0.783 & 2.44 \\
\hline RM5599 & 11 & 5 & $119-175$ & 56.667 & 1 & 0.62 & 51.22 \\
\hline RM25271 & 10 & 9 & $125-195$ & 28.571 & 1 & 0.844 & 4.88 \\
\hline RM25319 & 10 & 10 & 149-195 & 20.513 & 2 & 0.86 & 0 \\
\hline Total & & 192 & & & 25 & & \\
\hline Mean & & 6.4 & & 37.76 & 0.83 & 0.735 & 5.28 \\
\hline Min & & 3 & 65 & 13.95 & 0 & 0.447 & 0 \\
\hline Max & & 12 & 280 & 71.43 & 3 & 0.888 & 51.22 \\
\hline
\end{tabular}


Table 3. Unique allele and heterogeneity (HG\%) identified in 41 rice varieties

\begin{tabular}{|c|c|c|c|c|c|}
\hline \multirow{2}{*}{ Varieties Name } & \multirow{2}{*}{ Code } & \multicolumn{3}{|c|}{ Unique allele } & \multirow{2}{*}{$\mathrm{HG} \%$} \\
\hline & & Total & SSR marker & Size (bp) & \\
\hline Nhong Haiduong & 842 & 2 & RM25, RM1364 & 152,126 & 6.67 \\
\hline Khau nuot cung & 1832 & 2 & RM1364, RM3534 & 160,96 & 6.67 \\
\hline Lua mo trang & 1837 & 3 & RM267, RM495, RM5599 & 144,147 & 10 \\
\hline B'le tolo & 2125 & 0 & & & 0 \\
\hline Ble blu & 2127 & 1 & RM3476 & 165 & 3.33 \\
\hline Ble la tong & 2131 & 2 & RM1153, RM25319 & 135,184 & 6.67 \\
\hline Ble lenh xi & 2135 & 1 & RM3476 & 117 & 3.33 \\
\hline Nep cuc & 2367 & 1 & RM1367 & 100 & 3.33 \\
\hline Ble' la & 2642 & 1 & RM3468 & 170 & 3.33 \\
\hline Chanh trui & 3550 & 1 & RM566 & 261 & 3.33 \\
\hline Mong lu & 3935 & 0 & & & 0 \\
\hline Ble ch-cau & 3970 & 0 & & & 0 \\
\hline Khau lay khao & 4123 & 0 & & & 0 \\
\hline Cham soong & 4723 & 0 & & & 0 \\
\hline Nep cai can & 4726 & 0 & & & 0 \\
\hline Hang ngua & 4748 & 1 & RM1313 & 89 & 3.33 \\
\hline Lo cang & 4762 & 0 & & & 0 \\
\hline Khau ma giang & 4792 & 0 & & & 0 \\
\hline Khau non & 4793 & 0 & & & 0 \\
\hline Khau hin & 4794 & 0 & & & 0 \\
\hline Blao sinh sai & 4806 & 1 & RM267 & 162 & 3.33 \\
\hline Blao dong & 4840 & 1 & RM25271 & 185 & 3.33 \\
\hline Blao co nem & 4843 & 1 & RM3476 & 136 & 3.33 \\
\hline Khau noong mo & 5011 & 0 & & & 0 \\
\hline Chao luu & 5015 & 0 & & & 0 \\
\hline Khau san & 5018 & 0 & & & 0 \\
\hline Khau do don & 5020 & 0 & & & 0 \\
\hline Khau cu & 5057 & 1 & RM25319 & 175 & 3.33 \\
\hline Te tep & 6111 & 0 & & & 0 \\
\hline Cuom dang 1 & 6188 & 1 & RM5586 & 100 & 3.33 \\
\hline Ngoi tia & 6203 & 3 & RM1153, RM1313 & $90,76,144$ & 10 \\
\hline Khau ken & 6430 & 2 & RM1364, RM3436 & 169,209 & 6.67 \\
\hline Bieo hong sui & 6432 & 0 & & & 0 \\
\hline Manh gie & 7349 & 0 & & & 0 \\
\hline IR64 & 4666 & 0 & & & 0 \\
\hline Jasmine 85 & & 0 & & & 0 \\
\hline SL12 & & 0 & & & 0 \\
\hline DT54 & & 0 & & & 0 \\
\hline Khang Dan & 8177 & 0 & & & 0 \\
\hline Q5 & 8179 & 0 & & & 0 \\
\hline LT25 & & 0 & & & 0 \\
\hline Total & & 25 & & & \\
\hline Mean & & 0.61 & & & 2.03 \\
\hline $\operatorname{Max}$ & & 25 & & & 10 \\
\hline
\end{tabular}

accessions had at least two alleles at one (single) locus. Eleven accessions had the minimum HG percentage indicating a single heterogeneous locus (3.33\%).

Twenty five unique alleles detected are specific for 17 rice accessions (Table 3 ). All of these alleles detected in traditional rice varieties, and two varieties, Lua mo trang and Ngoi tia, harbored three unique alleles in each (Table 3).

\section{Cluster analysis}

The genetic similarities obtained from SSR data were used to create a cluster diagram. Cluster analysis based on Dice coefficients using UPGMA grouped 41 rice accessions into 2 main clusters I and II (Fig. 2). The cluster analysis represented a significant genetic variation among the rice accessions. The genetic similarity ranged from null for ten accessions pairs to 0.81 with a mean of 0.32 indicated a significant genetic variation among rice accessions. The highest value (0.81) corresponded to 'Khang Dan'-'DT54' pair (Table 4). The dendrogram revealed 2 distinct groups (I and II) at the Dice coefficient of 0.12 (Fig. 2). The first group (Group I) consists of 16 rice vari- 
Table 4. Genetic relationships among 41 rice accessions

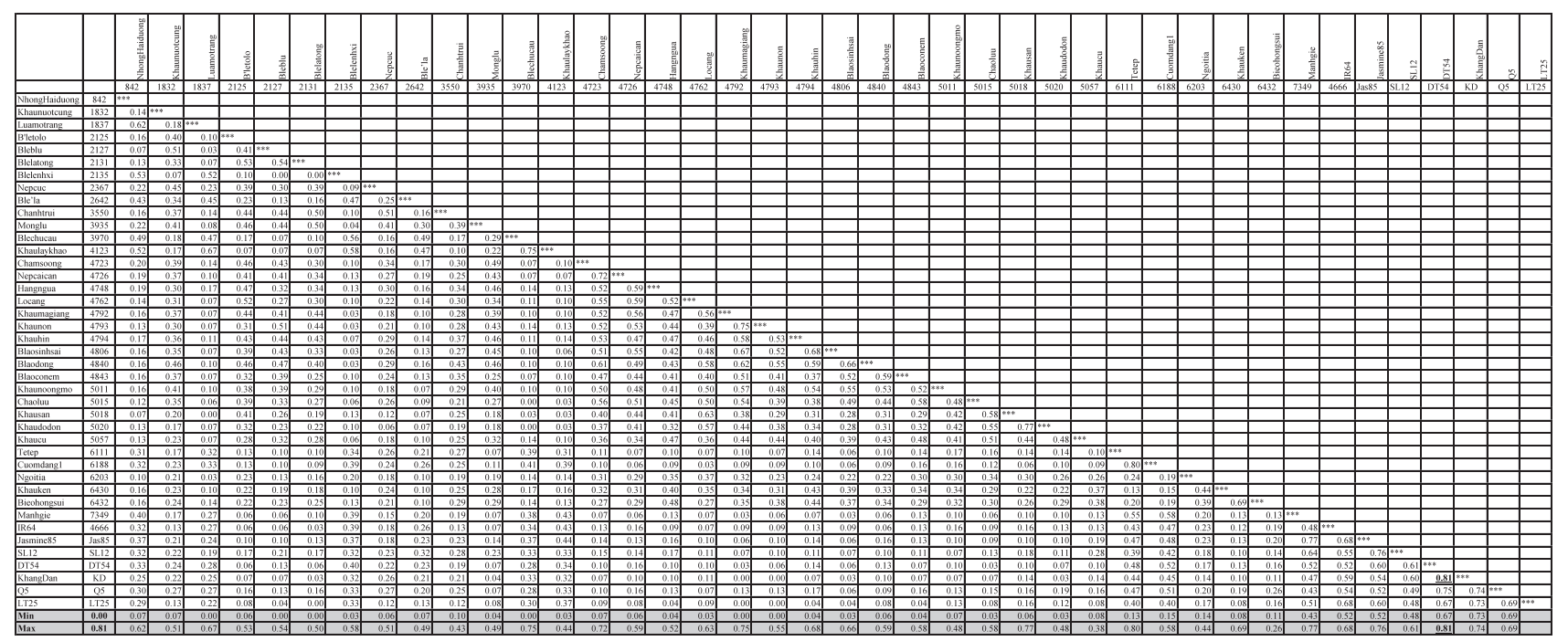

Genetic similarity were calculated using Dice coefficient (Dice, 1945; Nei and Li, 1979).

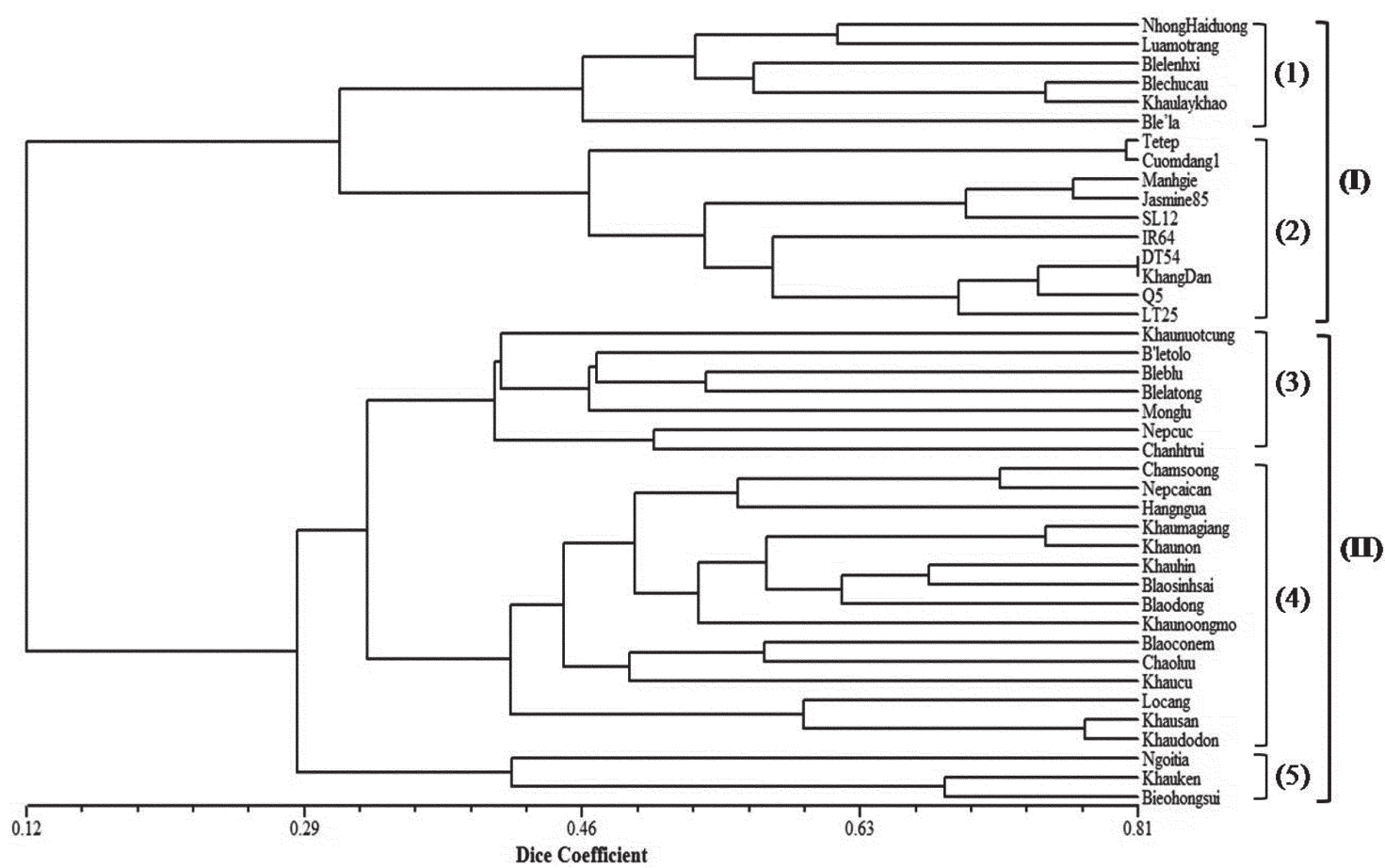

Fig. 2. Dice's similarity coefficient based on 30 SSR makers showing the relationships among 41 rice accessions. Dendrogram derived from UPGMA cluster analysis. (1) - (5): sub group; (I), (II): group.

eties with the Dice coefficients ranged between $\sim 0.32$ and 0.81. The second group (Group II) consists of 25 remaining accessions, with the genetic coefficients ranged between $\sim 0.29$ and 0.76 . Group I was further sub-divided into several sub-groups. All of 7 commercial varieties (Jasmine85, SL12, IR64, DT54, Khang Dan, Q5, and LT25) were clustered in one sub-group with three other varieties (Tetep, Cuom dang1, and Manh gie). The second group (Group II) was also further sub-divided into three sub-groups, consisted of 7,15 , and 3 varieties, respectively (Fig. 2). Cluster analysis had grouped most of the traditional upland varieties together showing a high level of genetic relatedness.

\section{DISCUSSION}

The number of studies have been performed for genetic diversity in different rice germplasm using molecular markers (Nagaraju et al., 2002; Yu et al., 2003; Gao et al., 2005; Jeung et al., 2005; Herrera et al., 2007; Wong et al., 2009). In this study, we present a genetic diversity analysis of upland drought tolerant and improved Vietnamese rice varieties based on microsatellite marker data. We evaluated 30 SSR markers in 41 rice varieties, seven of these genotypes represent indica varieties commercially cultivated in Vietnam, originated from China, Thailand and IRRI. The other 34 genotypes rep- 
Table 5. Genetic diversity of different rice germplasms

\begin{tabular}{|c|c|c|c|c|c|c|c|}
\hline \multirow[b]{2}{*}{ Author } & \multirow[b]{2}{*}{$\begin{array}{c}\text { No of } \\
\text { accessions }\end{array}$} & \multirow[b]{2}{*}{$\begin{array}{l}\text { No of } \\
\text { marker }\end{array}$} & \multirow[b]{2}{*}{$\begin{array}{l}\text { No of } \\
\text { allele }\end{array}$} & \multicolumn{4}{|c|}{ Average } \\
\hline & & & & $\begin{array}{c}\text { Allele } \\
\text { number }\end{array}$ & PIC & $\begin{array}{l}\text { Number of } \\
\text { unique alleles } \\
\text { (rare allele*) }\end{array}$ & $\begin{array}{l}\text { HG } \\
(\%)\end{array}$ \\
\hline Giarrocco et al., 2007 & 69 & 26 & 219 & 8.4 & 0.69 & 1.7 & 3.4 \\
\hline Wong et al., 2009 & 8 & 12 & 31 & 2.6 & 0.52 & - & - \\
\hline Nagaraju et al., 2002 & 24 & 19 & 70 & 3.8 & - & - & - \\
\hline Alvarezet et al., 2007 & 50 & 10 & 66 & 6.6 & 0.74 & 1.4 & - \\
\hline Thomson et al., 2007 & 330 & 30 & 394 & 13.1 & 0.66 & $9^{*}$ & - \\
\hline Herrera et al., 2008 & 18 & 48 & 203 & 4.2 & 0.52 & - & - \\
\hline Yu et al., 2003 & 193 & 101 & 628 & 6.2 & 0.68 & - & - \\
\hline Chakravarthi et al., 2006 & 15 & 30 & 462 & - & - & - & - \\
\hline This study & 41 & 30 & 192 & 6.4 & 0.73 & 0.6 & 5.3 \\
\hline
\end{tabular}

resent Vietnam traditional and upland varieties (Table 1). A total of 192 alleles were detected with an average number of alleles of 6.4 per locus (ranged from 3 to 12 per locus). This value is higher than those reported for the studies performed on smaller germplasm sets (Nagaraju et al., 2002; Herrera et al., 2007; Wong et al., 2009) and comparable to values reported in Yu et al. (2003), Alvarez et al. (2007), but quite lower than those reported for other large scale collection (Giarrocco et al., 2007; Thomson et al., 2007) (Table 5). The results demonstrated that the varieties selected possess a high level of microsatellite variation $(\mathrm{PIC}=0.73)$. The overall genetic diversity (PIC $=0.73$ ) of the 41 rice germplasm accessions included in this study was similar to the value reported in previous studies ( $\mathrm{PIC}=0.74$ ) (Gao et al., 2003; Alvarez et al., 2007; Ghneim et al., 2008), but higher than those reported in the studies: Yu et al. (2003) reported a PIC value of 0.68 using 193 accessions, Xu et al. (2004) reported 0.66 using 236 accessions, Garris et al. (2005) reported 0.67 using 334 accessions, and Giarrocco et al. (2007) reported 0.69 using 69 accessions. The results presented in this study suggest the genetic basis of the local upland and traditional Vietnamese rice varieties is desirably broad.

Based on phenotypic characteristics (data not shown) and information supplied by Gene Bank on the origin of the varieties, we hypothesize that traditional upland rice represents alternative genetic pools to those presented in the improved cultivars. The same observation was found for Cuban rice varieties (Alvarez et al., 2007). The hypothesis was also corroborated by cluster analysis based on genetic relationship estimates (Fig. 2). As expected, all the improved varieties grouped in the same genetic group (group I), confirming the close relationship. The cluster of some traditional upland varieties in group I suggested their close genetic relationship with improved varieties. The Gene Bank information also indicated the indica relationship among these varieties. Out of 16 accessions of Group I, four improved cultivars LT25, Q5, Khangdan and DT54 were clustered together in one subgroup, which cultivated in lowland conditions.
The cultivar IR64 introduced from IRRI was placed alone in a subgroup. The varieties Cuomdang1, a traditional adapted to salinity condition was placed together with Tetep in one subgroup. The other six traditional varieties clustered in one subgroup, which originated either from Red river Delta or Northwest region (Fig. 2). This indicated the varieties clustered into one subgroup came from the same origin, representing the alternative genetic pools.

In the dendrogram assembled for the 41 rice accessions (Fig. 2), there was a relatively positive correlation between cluster groupings and geographic distance. For example, most of the rice accessions from the North Central and Northwest provinces of Vietnam were clustered into group II comprised 25 varieties and consisted of three subgroups. The similarity coefficient of this group ranged from 0.29 and 0.76 . The phenotypic evaluation on drought tolerance exhibited high level of tolerance to water deficit of these traditional upland varieties (data not shown).

There are few studies which have been performed in genetic diversity survey for Vietnamese rice germplasm (Fukuoka et al., 2006; Lang et al., 2009) using molecular markers (RAPD) and phenotypic profiles. Vietnamese upland varieties used in the present study have not been examined previously in term of genetic relatedness using molecular markers. The high genetic diversity was found among the Vietnamese traditional accessions, and evidences of the broad genetic bases can be used in our breeding program. Comparison between results of this study and previous similar works of different rice germplasms showed high level of genetic diversity for Vietnamese rice germplasm (Table 5). Based on phenotypic evaluation data provided by National Gene Bank, the traditional rice varieties showed resistance to different diseases and adapted to abiotic stress conditions. This germplasm can provide potential gene sources for breeding program. Our results indicated that it is essential to broaden the genetic base of the cultivated rice to reduce its vulnerability to diseases and insect resistance, to enhance its ability to stress conditions. Recent studies 
showed that there is still a tremendous amount of unexploited genetic diversity in the primary gene pool of rice that can be used for enhancing the diversity in local germplasm and their performance under diverse agro- ecological conditions (Yu, 2003; Pfeiffer et al., 2005; Lafitte et al., 2006; Thomson, 2007; Herrera, 2008; Wong, 2009).

The correct identification of genetic diversity of varieties in the local germplasm is important for rice breeding programs, allowing selection of the desired rice accessions for crossing. Thus, the determination of the genetic distance among the accessions will be important to maximize their use in breeding program. Furthermore, the assessment of genetic diversity of rice germplasm present in the collection will help breeder to formulate crosses by choosing varieties with different genetic backgrounds and will assist in the development of mapping populations with high level of marker polymorphism (Alvarez et al., 2007; Jayamani et al., 2007).

In conclusion, this is the first study on characterization of the molecular diversity in traditional drought tolerant upland rice originated from Northern part of Vietnam. The phenotyping and SSR fingerprinting data showed high level of genetic diversity in this germplasm. The data will be useful to Vietnam rice breeders by improving the selection of parental lines for cross and enhancing plasticity or resistance of the cultivars.

\section{ACKNOWLEDGEMENTS}

This work was conducted at Agricultural Genetics Institute and financially supported by National Foundation for Science and Technology (Nafosted), Vietnam. We also acknowledge Plant Resource Center for kindly providing the rice materials from National Gene Bank, Hanoi, Vietnam. The authors of this paper would like to acknowledge the kind advice of Jeff Stein from Donald Danforth Plant Science Center, USA.

\section{REFERENCES}

Akagi, H., Y. Yokozeki, A. Inagaki and T. Fujimura 1997 Highly polymorphic microsatellites of rice consist of TA repeats, and a classification of closely related cultivars with these microsatellite loci. Theor. Appl. Genet., 94: 61-67

Alvarez, A., J. L. Fuentes, V. Puldón, P. J. Gómez, L. Mora, M. C. Duque, G. Gallego and J. M. Tohme 2007 Genetic diversity analysis of Cuban traditional rice (Oryza sativa L.) varieties based on microsatellite markers. Genet. Mol. Biol., 30(4): 1109-1117

Anderson J. A., G. A. Churchill, J. E. Autrique, S. D. Tanksley and M. E. Sorrells 1993 Optimizing parental selection for genetic linkage maps. Genome, 36: 181-186

Botstein, D., R. L. White, M. Skolnick and R. W. Davis 1980 Construction of a genetic linkage map in man using restriction fragment polymorphisms. Am. J. Hum. Genet., 32: $314-331$

Bray, E. A., J. Bailey-Serres and E. Weretilnyk 2000 Responses to abiotic stresses. In $\mathrm{W}$ Gruissem, B Buchannan, $\mathrm{R}$ Jones, eds, Biochemistry and Molecular Biology of Plants. American Society of Plant Physiologists, Rockville, MD, pp. 1158-1249

Chakravarthi, K. B. and R. Naravaneni 2006 SSR marker based DNA fingerprinting and diversity study in rice (Oryza sativa L). Afr. J. Biotech., 5(9): 684-688

Dice, L. R. 1945 Measures of the amount of ecologic association between species. Ecology, 26: 297-302

Florence, C., Lasalita-Zapico, J. A. Namocatcat and J. L. CarinoTurner 2010 Genetic diversity analysis of traditional upland rice cultuvars in Kihan, Malapatan, Sarangani province, Philippines using morphometric markers. Philipp. J. Sci. 139 (2): $177-180$

Fukuoka S., D. S. Tran, K. Ebana, N.T. Luu, T. Nagamine and K. Okuno 2006 Diversity in phenotypic profiles in landrace populations of Vietnamese rice: A case study of agronomic characters for conserving crop genetic diversity on farm. Gen. Res. and Crop Evolution, 53(4): 753-761

Gao, L., B. A. Schaal, I. Jia and Y. Dong 2003 Assessment of population genetic structure in common wild rice Oryza rufipogon Griff. using microsatellite and allozyme markers. Theor. Appl. Genet., 106: 1631-1638

Gao, L. Z. 2005 Microsatellite diversity and population genetic structure of an endangered wild rice, Oryza officinalis (Poaceae) from China. Mol. Ecol., 14: 4287-4297

Garris, A. J., T. H. Tai, J. Coubur, S. Kresovich and S. McCouch 2005 Genetic structure and diversity in Oryza sativa L. Genetics, 169: 1631-1638

Ghneim, T., D. P. Duque, I. Petez, G. Torrealba, A. J. Pieters, C. P. Martinez and J. M. Tohme 2008 Assessment of genetic diversity in Venezuelan rice cultivars using simple sequence repeats markers. Electron. J. Biotechnol., 11: 1-13

Giarrocco, L. E., M. A. Marassi and L. Salerno 2007 Assessment of the genetic diversity in Argentina rice cultivars with SSR markers. Crop Sci., 47: 853-860

Herrera, T. G., D. P. Duque, I. P. Almeida, G. T. Núñez, A. J. Pieters, C. P. Martinez and J. M. Tohme 2008 Assessment of genetic diversity in Venezuelan rice cultivars using simple sequence repeats markers. Electron. J. Biotechnol., 11(5): 14

Jackson, M. T. and R. Juggan 1993 Sharing the diversity of rice to feed the world. Diversity, 9: 22-25

Jayamani, P., S. Negrao, B. Martins, B. Macas and M. Oliveria 2007 Genetic relatedness of Portuguese rice accession from diverse origin as assessed by microsatellite marker. Crop Sci., 47: 879-886

Jeung, J. U., H. G. Hwang, H. P. Moon and K. K. Jena 2005 Fingerprinting temperate janponica and tropical indica rice genotypes by comparative analysis of DNA markers. Euphytica, 146(3): 239-251

Junjiam, N., M. C. Peter and J. Mackill 2002 Evaluation of genetic diversity in rice subspecies using microsatellite markers. Crop Sci., 42: 601-607

Lafitte, H. R., Z. K. Li, C. H. M. Vijayakumar, Y. M. Gao, Y. Shi, J. L. Xu, B. Y. Fu, S. B. Yu, A. J. Ali, J. Domingo, R. Maghirang, R. Torres, D. Mackill 2006 Improvement of rice drought tolerance through backcross breeding: evaluation of donors and selection in drought nurseries. Field Crop Res., 97 $77-86$

Lang, N. T., P. T. B. Tu, N. C. Thanh, B. C. Buu and A. Ismail 2009 Genetic diversity of salt tolerance rice landraces in Vietnam. Plant Breeding Crop Sci., 1(5): 230-243

Nagaraju, J., M. Kathirvel, K. R. Ramesh, E. A. Siddiq and E. H. Seyed 2002 Genetic analysis of traditional and evolved Basmati and non-Basmati rice varieties by using fluorescence-based ISSR-PCR and SSR markers. PNAS, 99(9): $5836-5841$

Nei, M. and W. H. Li 1979 Mathematical model for studying genetic variation in terms of restriction endonucleases. Proc. Natl. Acad. Sci. 76: 5269-5273

Roussel, V., J. Koenig, M. Beckert and F. Balfourier 2004 Molecular biodiversity in French bread wheat accession related to temporal trends and breeding program. Theor. Appl. Genet., 108: 920-930

Sneath, P. H. A. and R. R. Sokal 1973 Numerical taxonomy: The principles and practice of numerical classification. W. H. Free-man, San Francisco, CA.

Spada, A., R. Mantegazza, M. Biloni, E. Caporali and F. Sala 2004 Italian rice varieties: Historical data, molecular markers, and pedigree to reveal their genetic relationships. Plant Breed. 
123: $1005-1011$

Tautz, D. 1989 Hypervariability of simple sequences as a general source for polymorphic DNA markers. Nucleic Acids Res., 17: 6463-6471

Thomson, M. J., E. M. Septiningsih, F. Suwardjo, T. J. Santoso, T. S. Silitonga and S. R. McCouch 2007 Genetic diversity analysis of traditional and improved Indonesian rice (Oryza sativa L.) germplasm using microsatellite markers. Theor. Appl. Genet., 114: 559-568

Vos, P., R. Hogers, M. Bleeker and Reijans 1995 AFLP: A new technique for DNA fingerprinting. Nucleic Acids Res., 23: 4407-4414

William, J. G. K., A. R. Kubelik, K. J. Livak, J. A. Rafalski and S. V. Tingey 1990 DNA polymorphism amplified by arbitrary primers are useful as genetic markers. Nucleic Acids Res., 18: $6531-6535$

Wang H. M. Qi and A. J. Cutler 1993 A simple method of preparing plant samples for PCR. Nucleic Acids Res., 21(17): 4153-4154
Wong, S. C., P. H. Yiu, S. T. W. Bong, H. H. Lee, P. N. P. Neoh and A. Rajan 2009 Analysis of Sarawak Bario Rice Diversity Using Microsatellite Markers. Am. J. Agr. Biol. Sci., 4(4) 298-304

Xu, Y., H. Beachell and S. R. McCouch, 2004 Marker-based approach to broadening the genetic base of rice in the USA. Crop Sci., 44: 1947-1959

Yongwen, Q. I., D. Zhang, H. Zhang, M. Wang, J. Sun, X. Wei, Z. Qiu, S. Tang, Y. Cao, X. Wang and Z. Li 2006 Genetic diversity of rice cultivars (Oryza sativa L.) in China and the temporal trends in recent fifty years. Chinese Sci. Bull., 51 681-688

Yu, S. B., W. J. Xu, C. H. M. Vijayakumar, J. Ali, B. Y. Fu, J. L. Xu Y. Z. Jiang, R. Marghirang, J. Domingo, C. Aquino, S. S. Virmani and Z. K. Li 2003 Molecular diversity and multilocus organization of the parental lines used in the International Rice Molecular Breeding Program. Theor. Appl. Genet., 108: 131-140 